\title{
Kritiese ekologiese kuns en Hegel se raaiselagtige uitspraak dat kuns moet sterf \\ Critical ecological art and Hegel's cryptic statement that art must die
}

\author{
Bert Olivier \\ Universiteit van die Vrystaat \\ Bloemfontein \\ Suid-Afrika \\ E-pos: OlivierG1@ufs.ac.za
}

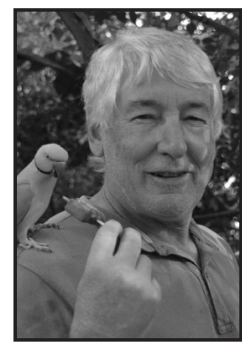

Bert Olivier

\begin{abstract}
Bert Olivier is Buitengewone Professor in Filosofie aan die Universiteit van die Vrystaat, Suid-Afrika. Sy werk is interdissiplinêr en hy het artikels en boeke oor' $n$ breë verskeidenheid van dissiplines soos filosofie, letterkunde, psigoanalise, sosiale teorie, argitektuur, kommunikasiestudies en filmteorie gepubliseer. In 2004 is die Stalsprys vir Filosofie deur die Suid-Afrikaanse Akademie vir Wetenskap en Kuns aan Bert toegeken, terwyl die Nelson Mandela Metropolitaanse Universiteit in 2012 'n Uitsonderlike Professorskap aan hom toegeken het. Hy is 'n B-gegradeerde navorser van die NNS en skryf ook gereeld op die Mail and Guardian Thoughtleader webwerf.
\end{abstract}

Bert Olivier's principal position is that of Extraordinary Professor of Philosophy at the University of the Free State, South Africa. He has published academic articles and books across a wide variety of disciplines, including philosophy, art theory, architecture, literature, psychoanalytic theory, cinema, communication studies and social theory. Bert received the South African Stals Prize for Philosophy in 2004, and a Distinguished Professorship from Nelson Mandela Metropolitan University in 2012. He is also an NRF B-rated researcher, and writes regularly on the Mail and Guardian's Thought leader-website.

\section{ABSTRACT}

\section{Critical ecological art and Hegel's cryptic statement that art must die}

Georg Wilhelm Friedrich Hegel (1770-1831), one of the major figures in the history of philosophy, played a significant role in the development of German idealism from Immanuel Kant in the 18th century via figures such as Schelling and Fichte, with the movement culminating in Hegel's "absolute idealism". In ontological terms idealism means that "the idea" is regarded as the true reality, instead of material things. Karl Marx, who learned a lot from Hegel as far as his dialectical method goes, famously remarked that Hegel had turned the world on its head, and he, Marx (a materialist thinker), would put it back on its feet again. 
Hegel made a substantial contribution to the philosophy of art-his multi-volume work, Lectures on Aesthetics, is justly famous - but instead of discussing it here in general terms, I shall focus on Hegel's puzzling statement that art had reached the highest point of its development as bearer of "the idea" in his own time (the first half of the 19th century), and would have to make way for religion and philosophy as expressions of the idea, or spirit/mind. This is known as Hegel's thesis of "the death of art". One might wonder what this means, because anyone can see that, if he meant the end of art as a cultural practice, he was simply wrong, given the ubiquitous signs of ongoing artistic activities. This may be the case, but recall that Hegel saw art as having reached the highest point of its development as bearer of "the idea" at that time, suggesting that there would still be a role for art after this point. This is precisely what is the case.

For Hegel, the idea, or spirit (mind) as ultimate reality, unfolds itself in the history of the world at various levels. At the niveau of social and political development, which Hegel writes about in his Philosophy of History, he understands history from the ancient Chinese, Indians and Persians, through the Greeks and Romans until his own time as the history of the increasing "consciousness of freedom", with every new era displaying a step forward, approximating the ideal of political freedom. In this, his most accessible work, as well as in his magnum opus, The Phenomenology of spirit/mind, Hegel displays what is probably his most lasting philosophical legacy - a keen awareness, more than any philosopher before him, of history, and the fact that everything human is subject to historical development, which he believed to have meaning and direction. Moreover, instead of a simple-minded, linear conception of history, he thinks of historical change dialectically - that is, developing from one state of affairs through its negation by its dialectical opposite, or antithesis, to another, higher state, which comprises a synthesis of the two preceding stages. This new stage is again negated by its opposite, and so on.

Importantly, however, Hegel claims that, with every dialectical movement from one historical condition to another, the previous, negated stage is preserved, uplifted, and cancelled simultaneously (a tripartite process called sublation in English, and Aufhebung in German). This means that every earlier stage of development is still present in every later stage, but in a transformed fashion. Hegel also calls this "the negation of the negation" - incorporating something of the other into oneself. To reach the level of what he calls absolute spirit, it develops through subjective spirit (sense perception, consciousness, self-consciousness) and objective spirit (the family, the state, law) to the point where it manifests itself in art, followed by religion, and eventually the highest level, namely, philosophy, where absolute spirit or mind "knows itself" in clear conceptual terms. In the development of art he distinguishes three stages, namely symbolic art, classical art and the art of his own time, namely romantic art. Certain kinds of art correspond to these stages, with architecture being the exemplary symbolic art, sculpture the epitome of classical art, and painting, music and dramatic poetry the clearest expressions of romantic art. Moreover, in every stage, and kind of art there is a typical relationship between the idea and the material within which it is enveloped (for that is what art is, for Hegel: the sensuous, or material, embodiment of the idea).

In the case of symbolic art the idea does not appear clearly, but is only dimly suggested because the sensuous envelope predominates over it. The art of the ancient Egyptians serves as an example of symbolic art, with the Sphinx as "the symbol of the symbolic". Classical art is exemplified by ancient Greek sculpture, which is in a sense the "highest" that art is capable of as far as the relationship between idea and matter goes: in the sculptures depicting the Greek gods, such as Apollo, we see the perfect equilibrium, Hegel claims, between idea and 
matter, with neither dominating the other. However, when romantic art replaces classical art we find a preponderance that is the opposite of that found in symbolic art, insofar as the idea becomes too strong for the material to contain, so that it threatens to break its material bonds. Hegel sees this happening in the painting, music and poetry or drama of his time. Think of romantic paintings such as those of Eugene Delacroix or Theodore Gericault, for example, the latter's painting of The Raft of the Medusa, which commemorates the sinking of a ship by that name and shows survivors on a raft, in various stages of exhaustion and desperation. It is as if the painting is striving to surpass itself as artistic medium in an attempt to express the suffering of these people. The same is true of some of the music of Hegel's time. He would probably have been familiar with Beethoven's opera. Fidelio - with its valorisation of love, courage, sacrifice and freedom - although he does not refer to it. But it is particularly poetry and drama, where the poetic expressions of joy and suffering come close to philosophy (except that here they are instances of imaginative, instead of conceptual articulations), that testify to romantic art signalling the finale of art's capacity to embody the idea. Art passes the baton to religion, which Hegel thinks of as "pictorial thinking", and which expresses the subjectivity of humans and of God better than art could. Eventually religion has to make way for philosophy, though, because it is there that spirit or mind knows itself self-reflectively and clearly.

As far as art is concerned there is an important corollary, however. Hegel writes about a "free art" that continues to exist after art has relinquished its "highest vocation", and attributes to this art a critical, polemical function, given that the artist has become free from the constraints of a specific worldview. In this respect Hegel seems to have been prescient; even in his own time he noticed that people had become less interested in merely looking at art, for instance, and more interested in what art meant - hence Hegel's anticipation of a "science of art". Beyond Hegel's lifetime art developed in a manner that bears out his expectations. Particularly in the early 20th century one notices a plethora of new art movements - abstract expressionism, cubism, fauvism, conceptualism, suprematism, futurism, metaphysical art-all of which bear overtly theoretical names, claiming to reflect the true nature of reality. In contemporary ecological art, such as that of Andy Goldsworthy, one may perceive a particularly powerful instance of the "critical" role of art that Hegel anticipated. It is here discussed to demonstrate what is meant by claiming that it embodies a "radically critical" art in the face of the ecological crisis facing humanity.

KEYWORDS: death of art, critical art, ecological art, dialectical, Hegel, history, capitalism, Goldsworthy

TREFWOORDE: dood van kuns, kritiese kuns, ekologiese kuns, dialekties, Hegel, geskiedenis, kapitalisme, Goldsworthy

\section{OPSOMMING}

Georg Wilhelm Friedrich Hegel (1770-1831), een van die belangrikste figure in die ontwikkeling van Duitse idealisme, se filosofie staan as "absolute idealisme" bekend, aangesien hy die idee, of gees (verstand) as die eintlike werklikheid beskou - in teenstelling met 'n materialistiese denker soos Karl Marx, wat materie (stof) as primêre werklikheid aanwys. Hegel was die eerste Westerse denker wat die geskiedenis ernstig opgeneem het; volgens hom is alles, spesifiek menslike kulturele aktiwiteite, onderworpe aan historiese ontwikkeling, en beskryf hy hierdie ontwikkeling op verskeie vlakke, insluitende dié wat hy "absolute gees" noem. Op hierdie vlak word wêreldgeskiedenis aan die hand van 'n "dialektiese" ontwikkeling vanaf "subjektiewe" gees (individuele menslike passies en bedoelinge) via "objektiewe" gees (staatstrukture en 
wette) tot "absolute gees" voorgestel. In hierdie artikel word daar aandag gegee aan wat volgens Hegel op laasgenoemde vlak gebeur, spesifiek met betrekking tot sy raaiselagtige stelling, dat die kuns as "hoogste uitdrukking" van die gees "moet sterf", om plek te maak vir religie en filosofie as manifestasies daarvan op meer gevorderde vlakke. 'n Mens kan tereg wonder wat Hegel daarmee bedoel het in die lig van die voortdurende beoefening van kuns tot vandag toe. Die antwoord is geleë in die frase, "hoogste uitdrukking", wat daarop dui dat hy aan kuns in historiese ontwikkelingsterme dink - met ander woorde, kuns is die draer van die absolute gees tot op 'n bepaalde tydstip, waarna dit plek moet maak vir ander sodanige uitdrukkingsvorme, te wete godsdiens en filosofie. Bowendien is kuns self ook onderworpe aan interne ontwikkeling; vir Hegel is die vroegste kuns simbolies van aard, (met Egiptiese kuns as voorbeeld), gevolg deur klassieke kuns (onder die antieke Grieke) en laastens romantiese kuns (in sy eie tyd). Die verskille tussen hierdie drie kunsvorms word bepaal deur die verhouding tussen idee en materie; in simboliese kuns domineer materie oor die idee in kunswerke, sodat die betekenis daarvan slegs vaagweg gepeil kan word (dink maar aan die Sfinks, as die "simbool van die simboliese"), terwyl daar ' $n$ volmaakte balans tussen idee en materie bestaan in klassieke Griekse kuns, sodat geeneen van die twee dominant is nie (soos in die geval van beeldhouwerke wat die god Apollo voorstel). In romantiese kuns (byvoorbeeld die romantiese skilderkuns van Gericault) vind 'n mens die teenoorgestelde van simboliese kuns, met die idee wat dermate oor die materie heers dat dit byna daarin slaag om in denkbeeldige vorm daarvan los te breek. Hierdie is volgens Hegel die "hoogste" ontwikkelingspunt wat kuns as draer van die gees kan bereik, voordat dit plek maak vir religie as "beelddenke" en uiteindelik filosofie, waar die gees as idee suiwer, sonder enige stoflike oorblyfsel, tot uitdrukking kom. Hier voltooi die absolute gees die ontwikkelingstrajek daarvan, wat by die objektiewe vergestalting daarvan begin en via subjektiewe beliggaming uiteindelik in absolute "selfkennis" kulmineer. Vir die doeleindes van hierdie artikel is dit egter tematies betekenisvol dat Hegel ook melding maak van die voortbestaan van kuns ná die punt waar dit afstand doen van die titel van "hoogste" manifestasie van die gees of idee, naamlik in die gewaad van "kritiese", polemiese kuns, wat vry geword het van spesifieke wêreldbeskouings. 'n Mens kan in die moderne kunsbewegings van die vroeë 20ste eeu - insluitende kubisme, abstrakte ekspressionisme, konseptualisme en futurisme - die beliggaming van hierdie verwagting by Hegel bespeur, waar hierdie soort kuns telkens die ontologiese aanspraak maak dat dit die ware werklikheid blootlê. As besonder treffende tydgenootlike uitdrukking van sodanige (radikale) kritiese kuns word Andy Goldsworthy se ekologiese kuns ten slotte onder die loep geplaas.

\section{INLEIDING: HEGEL, GESKIEDENIS EN KUNSFILOSOFIE}

The closer we come to the danger, the more brightly do the ways into the saving power begin to shine and the more questioning we become. (Heidegger, "The Question Concerning Technology", p. 35)

Georg Wilhelm Friedrich Hegel (1770-1831) was een van die belangrikste denkers van die Duitse idealisme, wat vanaf Immanuel Kant se transendentale idealisme via denkers soos Schelling (objektiewe idealis) en Fichte (subjektiewe idealis) strek om in sy sogenaamde "absolute idealisme" te kulmineer. In ontologiese terme beteken idealisme dat die "idee" as die ware werklikheid beskou word, in plaas van materiële dinge. Karl Marx, wat Hegel se dialektiese denkwyse oorgeneem en op materialistiese wyse benut het, is bekend vir sy opmerking dat hy die wêreld, wat deur Hegel op sy kop geplaas is, weer teruggesit het op sy voete. 
Hegel het 'n noemenswaardige bydrae tot die kunsfilosofie gemaak - sy lywige werk, The Philosophy of Fine Art (1975), waar hy onder andere vyf verskillende kunssoorte vanuit sy filosofiese perspektief ondersoek en sy bespreking met talryke voorbeelde illustreer, is met goeie rede beroemd. (In die verbygaan moet ek noem dat, aangesien die meeste lesers waarskynlik eerder Hegel se werke in Engelse vertaling sou raadpleeg as in die oorspronklike Duits, ek hier deurgaans na die Engelse weergawes van sy tekste verwys.) Dog in plaas van 'n algemene bespreking daarvan, konsentreer ek in hierdie artikel op Hegel se raaiselagtige stelling, dat kuns die "hoogste" punt in die ontwikkeling daarvan as "draer" van die "idee" in sy eie tyd (die eerste helfte van die 19de eeu) bereik het, en dat dit sou moes plek maak vir religie en filosofie - in daardie volgorde - as uitdrukkings van die idee, of van gees (verstand). Dit staan bekend as Hegel se tese van die "dood van die kuns". 'n Mens mag tereg wonder wat hy met hierdie kriptiese uitspraak bedoel het, aangesien dit ooglopend deur alomteenwoordige, steeds bestaande kunspraktyke weerspreek word. Sy opmerking word egter meer verstaanbaar in die lig daarvan dat hy kuns koppel aan die "hoogste" ontwikkeling waartoe dit as draer van die "idee" in staat is. So beskou, gee dit die indruk dat daar inderdaad nog 'n kulturele rol vir die kunste sou wees ná die verwesenliking van die "hoogste" roeping van die kuns. By nadere ondersoek blyk dit inderdaad die geval te wees.

Volgens Hegel ontvou die idee (of gees, verstand) as ware realiteit (Hegel 1979:63) sigself in die geskiedenis van die wêreld op verskeie vlakke. Op die niveau van sosiale en politieke ontwikkeling - waaroor Hegel breedvoerig in The Philosophy of History (2001) skryf - stel hy die geskiedenis vanaf die antieke Sjinese, Indiërs en Perse tot sy eie era voor as die geskiedenis van die toenemende bewussyn van Vryheid, waar elke nuwe era 'n voorwaartse stap betreffende die verwesenliking van die vryheidsideaal verteenwoordig. In hierdie werk, wat waarskynlik sy mees toeganklike teks is, sowel as in sy (minder toeganklike) magnum opus, The Phenomenology of spirit (2018), toon Hegel 'n ongeëwenaarde sensitiwiteit (meer as enige filosoof voor hom) vir die historiese proses, dit wil sê die insig dat alles onder die son onderworpe is aan historiese ontwikkeling, insluitende menslike doen en late. Daarbenewens ontwikkel die geskiedenis na sy mening in 'n sinvolle rigting, ofskoon dit nie in eenvoudige, lineêre terme verstaan kan word nie, maar veel eerder op "dialektiese" wyse bestudeer moet word (Hegel 2010:71-72, 741-748; 2018:40-41; Singer 1983:99-103) - dit beteken dat dit van die een omvattende toedrag van sake (die "tese") via die "negasie" daarvan deur die dialektiese teenoorgestelde toestand (die "antitese") na 'n ander, hoër toestand (die "sintese") ontwikkel. Hierdie dialektiese proses herhaal hom oor en oor in die historiese gang van sake.

Dit is belangrik om te verstaan wat Hegel se bekende dialektiese "beweging" op enige gegewe tydstip behels. Telkens wanneer 'n oorgang van die een historiese toestand na 'n ander plaasvind - 'n proses wat Hegel in konkrete historiese terme in sy geskiedenisfilosofie beskryf - word die vorige toedrag van sake nie slegs "negeer" nie, maar gelyktydig "bewaar" (gepreserveer), "opgehef" en gekanselleer" - 'n drieledige proses wat as “opheffing” bekend staan (Aufhebung in Duits; "sublation" in Engels). Dit behoort duidelik te wees dat "opheffing" hier meersinnig is vir sover dit na 'n historiese proses verwys waar die historiese "inhoud" van die verlede tegelykertyd in die hede gekanselleer word en progressief verander, terwyl alle voorafgaande historiese fases in omvormde gewaad in elke nuwe fase bewaar bly. Hierdie geniale insig van Hegel in die aard van die historiese proses kom dus daarop neer dat elke historiese ontwikkelingstadium steeds aanwesig bly in elke latere fase, ofskoon dit in 'n omvormde (getransformeerde) gewaad is. Hegel noem hierdie inlywing van die voorafgaande ontwikkelingsfase by die latere stadium die "negasie van die negasie" (Hegel 2018:62-65). 
Ten einde die vlak van wat Hegel "absolute gees" noem, te bereik, ontwikkel dit deur wat hy benoem as "subjektiewe gees" (individuele sintuiglike waarneming, bewussyn, selfbewussyn), en "objektiewe gees" (die gesin, gemeenskappe, en instellings soos moraliteit, wette en sosiale etiek) tot by die vlak van "absolute gees". Laasgenoemde word eerstens volgens sy kunsfilosofie (of estetika) in die verskillende kunsvorme gemanifesteer en daarná, in ooreenstemming met sy filosofie van die godsdiens, in verskillende godsdienste gekontinueer. Laastens, volgens sy geskiedenis van filosofieë, word absolute gees in filosofie as hoogste uitdrukking daarvan gemanifesteer (Hegel 2018:390-467) - wat terselfdertyd die kulminering is van die gees se selfkennis, nadat dit deur al die dialektiese stadia van relatiewe selfvervreemding gegaan het.

In die ontwikkeling van kuns en die verskillende kunste onderskei Hegel (1979:7-13, 73, 75-83, 89-90) drie stadia, te wete simboliese, klassieke en romantiese kuns - die kuns van sy eie tyd. Volgens hom korrespondeer argitektuur met simboliese kuns as die paradigmatiese uitdrukking daarvan, terwyl beeldhou die eksemplariese klassieke kuns, en skilderkuns, musiek, asook dramatiese digkuns die toonbeeld van romantiese kuns daarstel. Bowendien kan 'n kenmerkende verhouding tussen die idee en die materiële "omhulsel" daarvan bespeur word - volgens Hegel is kuns juis die sinlike, of stoflike, beliggaming van die idee. In die geval van simboliese kuns kom die idee nie duidelik na vore nie, aangesien dit slegs vaagweg voor die gees geroep word vanweë die materiële element se oorheersende rol. Die kuns van antieke Egipte dien as voorbeeld van simboliese kuns, en 'n mens kan sê dat die enigmatiese Sfinks by Giza as die "simbool van die simboliese" beskou kan word. Op sy beurt vind klassieke kuns sy beliggaming in antieke Griekse beeldhouwerk, wat in 'n bepaalde sin die "hoogste" vlak verteenwoordig waartoe kuns volgens Hegel in staat is sover dit die verhouding tussen die idee en materie betref. So vind 'n mens in die beeldhouwerke van die Griekse gode (soos Apollo) die volmaakte balans, so meen Hegel, tussen idee en stof, sonder dat die een die ander oorheers. Wanneer die fase bereik word waar romantiese kuns klassieke kuns vervang, is 'n mens getuie van die omgekeerde verhouding tussen gees en materie as wat by simboliese kuns die geval was: hierdie keer is dit die gees wat die oorhand het oor die materie omdat die idee, volgens Hegel, te "sterk" geword het vir die stoflike "omhulsel" om in toom te hou, sodat dit daartoe neig om uit die sinlike bande waarin dit gegiet is te breek.

Hegel sien bogenoemde ontwikkelinge bevestig in die skilderkuns, musiek en digkuns van sy eie tyd. Dink maar aan die romantiese skilderye van Caspar David Friedrich, Eugene Delacroix en Theodore Gericault - byvoorbeeld laasgenoemde se opspraakwekkende skildery, The Raft of the Medusa, wat die desperate, uitgeputte oorlewendes van die vergane skip met die naam Medusa voorstel, waar hulle wanhopig op 'n vlot in die see ronddobber. Wat Hegel in hierdie kuns van die romantiek raakgesien het, is dat dit waarlik voorkom asof die skildery worstel om uit die artistieke medium te breek om die lyding van die mense op die vlot ten volle uit te druk. Dieselfde kan van die musiek en digkuns van die era beweer word - Hegel sou waarskynlik bekend gewees het met Beethoven se opera, Fidelio - waarin liefde, moed, opoffering en vryheid getematiseer word - al verwys hy, sover ek kon vasstel, nie uitdruklik daarna nie. Dit is egter veral in die romantiese drama en digkuns van die tyd waar poëtiese uitdrukkings van vreugde en lyding filosofiese insig benader, ofskoon 'n mens hier met beeldryke artistieke ekspressie te make het, eerder as met begripmatige filosofiese artikulasie. Terselfdertyd kan 'n mens volgens Hegel hierin duidelike aanduidings lees dat kuns 'n versadigingspunt bereik het wat die vermoë daarvan betref om die idee toereikend te beliggaam, en dat ' $n$ ander medium benodig word om hierdie rol van kuns oor te neem. Die fakkel word derhalwe oorgegee aan godsdiens, wat Hegel as "beelddenke" ("pictorial thinking") bestempel, en wat die subjektiwiteit van mense en van God volgens hom beter uitdruk as wat enige 
kunsvorm dit kan doen. Uiteindelik moet godsdiens egter plek maak vir filosofie, waarin gees of verstand sigself helder en duidelik in self-reflektiewe, begripmatige terme leer ken.

\section{WAAROM MOET DIE KUNS AS “HOOGSTE" DRAER VAN DIE GEES TOT 'N EINDE KOM?}

Volgens Hegel is daar drie spesifieke historiese redes vir die tot-einde-kom van die kuns: die Christendom, die moderne wêreld ná die Verligting, en die ineenstorting van die kuns in die romantiese kuns van sy tyd (Hegel 1975, Vol II:377-378). Wat die Christendom betref, verteenwoordig dit vir Hegel 'n vorm van waarheidsbemiddeling wat kuns as sodanig oortref, en waardeur die ware subjektiwiteit van die mens en van die goddelike vir die eerste keer tot uitdrukking kom (Oelmüller 1969:244-248), omdat die kuns dit nie langer met die middele tot die beskikking daarvan, toereikend kan voorstel of beliggaam nie. Hierdie ontoereikendheid van die kuns het veral met die mensdom se diepste vervreemding en versoening te make. In die tweede plek skiet die kuns eweneens tekort betreffende die kapasiteit daarvan om die moderne wêreld as sinlike, waarneembare totaliteit tot uitdrukking te bring - dit wil sê om die sosio-politieke werklikheid wat sedert die Verligting en die Franse Rewolusie gestalte aangeneem het in al die kompleksiteit daarvan waarneembaar te maak. Kuns was weliswaar in staat om hierdie taak uit te voer met betrekking tot die heroïese wêreld waarin die handeling afgebeeld in die oorspronklike (Homeriese) epiese gedigte afgespeel het, maar dit was volgens Hegel nie meer die geval nie - iets waartoe die Christendom, die tegniese en ekonomiese rewolusies van die industriële samelewing, asook die moderne burokraties georganiseerde staat deurslaggewend bygedra het. Die rede hiervoor het te make met die verskil tussen die Homeriese en Shakespeariaanse wêrelde, enersyds, waarin die eenheid tussen moreel outonome figure en die politieke en morele totaliteit in die kuns voorgestel kon word, en, andersyds, die toenemend komplekse struktuur van die moderne samelewing, wat nie vir die kuns toeganklik is soos vantevore nie, en waarin die individu dus nie meer soos vroeër artistiek uitgebeeld kan word nie. Karelis (in Hegel 1979:xlvii) verduidelik dit as volg:

Art is limited by its sensuous medium to the behaviour of individuals. It cannot portray anything so complex as a legal and institutional system. Thus while heroic autonomy can be presented in art, the autonomy of the bourgeois individual can be made evident only through the medium which grasps systems as wholes - philosophy. To all sensuous appearances, as it were, the free individual in the modern state is a cog in a machine he does not control. So if beauty is sensuously perceivable autonomy, secular characters in the romantic world cannot be beautiful...

Die derde begronding vir Hegel se oortuiging rakende die ondergang van die kuns sover dit die hoogste roeping daarvan as waarheidsbemiddelaar betref, het (paradoksaal genoeg) volgens hom te make met die opvallende agteruitgang van die kuns en die letterkunde gedurende sy tyd, wat bevestig dat hierdie "logies-dialektiese" noodsaaklikheid inderdaad histories gerealiseer is (Hegel 1975, Vol II:377-378, 388-397; sien ook Oelmüller 1969:252-264, vir sy siening van Hegel se mening dat kuns moet “sterf"). Eerstens word sodanige agteruitgang beklemtoon in sy opmerking (1988:103), dat "For us art counts no longer as the highest mode in which truth fashions an existence for itself" - iets wat hy toeskryf aan die veranderde (en veranderende) behoeftes van die menslike gees, wat vervolgens in religie, en daarná in filosofie, groter bevrediging vind. Soos hy dit stel, buig mense nie meer hul knie voor artistieke voorstellings van God, Christus en Maria nie (Hegel 1988:103). Wanneer ons ons na die letter- 
kunde van sy tyd wend, is dit treffend dat Hegel (1988:265-280) na letterkundige kunswerke verwys wat nie daarin slaag om die universele idee of Ideaal binne die partikuliere uit te lig nie (wat volgens hom die vervulling van ware kuns is) - en daarenteen óf die "subjektiewe" (die alledaagse bekende van die huidige tyd), óf die "objektiewe" (historiese besonderhede van die verlede ter wille van hulself) beklemtoon ten koste van die universele-in-die-besondere. Voorbeelde hiervan sluit selfs van Goethe se dramatiese werke in, byvoorbeeld Götz von Berlingen (Hegel 1988:270-271).

Wat die ontwikkeling en "dood" van die kuns(te), soos hier bo uiteengesit, betref, is daar egter 'n belangrike kwalifikasie. Hegel (1975, Vol. I:141-142) vestig die aandag op die verskyning, in sy eie tyd, van 'n nuwe soort kuns, naas dié van die Romantiek - 'n 'anderkant kuns" ("beyond [fine or beautiful] art”). Verder skryf hy (Hegel 1975, Vol. II:388-397) oor 'n "vrye kuns" wat bly voortbestaan nadat kuns die "hoogste roeping" daarvan as draer van die idee ingeboet het: "Art has become a free instrument which is qualified to exercise itself relatively to every content..." (ibid.:392). Hy skryf aan hierdie kuns 'n kritiese, polemiese funksie toe, wat te verstane is in die lig daarvan dat kunstenaars op hierdie historiese ontwikkelingsvlak bevry is van die beperkinge van 'n bepaalde wêreldbeskouing. In hierdie opsig blyk dit dat Hegel vooruitsiende was - selfs in sy eie tyd het die groei van die dissipline van estetika (soos in sy eie werk, asook dié van Immanuel Kant, Friedrich Schiller en Alexander Baumgarten in die 18de eeu) daarvan getuig dat mense toenemend in die (filosofiese of intellektuele) betekenis van kuns belangstel, en nie meer soseer om dit slegs te besigtig en te "ervaar" nie. Vandaar Hegel se antisipering van 'n "wetenskap van kuns", wat in sigself reeds simptomaties daarvan is dat kuns, in die "hoogste" funksie daarvan as kuns, tot 'n einde kom. In sy eie woorde (aangehaal in Harries 2009:65; sien ook Harries 1974, vir sy uitbreiding oor Hegel se "wet" van die dood van die kuns):

What is now aroused in us by works of art is over and above our immediate enjoyment, and together with it, our judgment; inasmuch as we subject the content and the means of representation of the work of art and the suitability and unsuitability of the work to our intellectual consideration. Therefore the science of art is a much more pressing need in our day than in times in which art, simply as art, was enough to furnish a full satisfaction. Art invites us to consideration of it by means of thought, not to the end of stimulating art production, but in order to ascertain scientifically what art is.

Sedert Hegel se leeftyd het die ontwikkeling van kuns, of die kunste, die akkuraatheid van sy verwagtinge bevestig. Dit is bowenal in die vroeë 20 ste eeu dat 'n stroom van nuwe kunsbewegings die lig sien, met opvallend teoretiese name - onder andere abstrakte ekspressionisme, kubisme, fauvisme, konseptualisme, suprematisme, futurisme en metafisiese kuns - wat implisiet daarop aanspraak maak om die ware ontologiese aard van die werklikheid te weerspieël, en dus Hegel se "voorspelling" van 'n "vrye kuns" bekragtig. Om die waarheid te sê, hierdie uiters teoreties georiënteerde kunsskole tref 'n mens byna as 'n soort sintese van "vrye [kritiese] kuns" en "teorie" (met ander woorde "kunswetenskap"). By 'n vorige geleentheid (Olivier 1998) het ek via die werk van Karsten Harries (1968) oor die betekenis van moderne kuns uitgewei oor die wyse waarop laasgenoemde gestalte gee aan Hegel se verwagting, wat dus daarvan 'n heeltemal verskillende artikel gemaak het; hier wil ek eerder op die intellektueel-kritiese funksie van tydgenootlike ekologiese kuns fokus, en meer spesifiek die uitsonderlike kuns van Andy Goldsworthy (wat ek vanuit 'n ander hoek by 'n vorige geleentheid benader het; Olivier 2007). Nie alleen verteenwoordig dit 'n vorm van die "vrye kuns" wat Hegel in die vooruitsig gestel het nie - met ander woorde, kuns wat nie meer aan 
'n bepaalde tyd of wêreldbeskouing gekoppel is nie - maar bowendien 'n besonder radikale voorbeeld daarvan, soos vervolgens aangetoon sal word.

\section{GOLDSWORTHY SE KRITIESE, POST-HEGELIAANSE EKOLOGIESE KUNS}

'n Mens mag aanvanklik wonder hoe op aarde "ekologiese kuns" gestalte kan gee aan Hegel se geprojekteerde vrye (kritiese of polemiese) kuns wat op die "dood" van die kuns as hoogste beliggaming van die gees sou volg. Immers, soos die naam aandui, het ekologiese kuns met sosiale en natuurlike ekologiese sisteme, met ander woorde, onder andere met die natuur te make. Soos ek sal probeer aantoon, is dit egter juis een van die mees "kritiese" kunsvorme van die huidige tyd, wat geensins verbasend is in die lig van die opvallende en onontkenbare ekologiese krisis van vandag nie, wat saamhang met globale verwarming en die moontlikheid van die einde van alle lewe op aarde (Kovel 2002; Diamond 2005; Foster et al. 2010; Princen 2010; Klein 2014; Pittaway 2017; Olivier 2014; Olivier 2018). Wat hier belangrik is, is die oorsake van die huidige ekologiese krisis. Uit die tersaaklike literatuur is dit onontkenbaar dat die moderne ekonomiese stelsel van (neoliberale) kapitalisme, wat op die beginsel van onbeperkte ekonomiese groei gebaseer is, en deurgaans weinig kennis geneem het van die eindigheid van die omvattende ekologiese sisteem, kousaal verantwoordelik is vir die steeds verergerende krisis (al is dit so dat kommunisme en sosialisme voor 1989 daartoe bygedra het). Immers: geen onbeperkte ekonomiese groei is binne 'n eindige ekosisteem moontlik nie, met die gevolg dat planetêre ekosisteme tans reeds breekpunt bereik het (Foster et al. 2010: 11-15). Joel Kovel (2002:5) som hierdie toedrag van sake as volg op:

...it has been proved decisively that the internal logic of the present system translates 'growth' into increasing wealth for the few and increasing misery for the many... 'growth' so conceived means the destruction of the natural foundation of civilization. If the world were a living organism, then any sensible observer would conclude that this 'growth' is a cancer that, if not somehow treated, means the destruction of human society, and even raises the question of the extinction of our species. A simple extrapolation tells us as much, once we learn that the growth is uncontrollable. The details are important and interesting, but less so than the chief conclusion - that irresistible growth, and the evident fact that this growth destabilizes and breaks down the natural ground necessary for human existence, means, in the plainest terms, that we are doomed under the present social order, and that we had better change it as soon as possible if we are to survive.

Die "kritiese" (post-Hegeliaanse) funksie van ekologiese kuns moet teen hierdie sosioekonomiese agtergrond verstaan word. Op aanbeveling van 'n welmenende kritikus moet bygevoeg word dat, in die lig van Kovel se kommentaar op onbeperkte kapitalistiese groei en die implisiete moontlikheid van die uitsterwing van die menslike spesie (asook ander lewensvorme), waarna vlugtig hier bo verwys is, daar inderdaad tans van die vooruitsig van 'n soort "einde" sprake is, wat radikaal van Hegel se tese van die "einde van die kuns" verskil. Immers: Hegel het slegs die einde van die kuns in 'n bepaalde beliggaming daarvan voorsien, saam met die historiese voortbestaan daarvan as "kritiese kuns". Hier staan ons egter voor die moontlikheid van 'n "finale" einde, indien die mensdom nie betyds tot hul sinne kom nie (Olivier 2018). Dit verskil dus ook van "die einde van die geskiedenis" soos deur Francis Fukuyama (1992) geformuleer is, wat bloot na die kulminering van die geskiedenis in die liberale demokrasie, asook die verdere oorbodigheid van alle ander voorafgaande politiekekonomiese stelsels verwys. Nodeloos om by te voeg, geld dieselfde vir Karl Marx se bekende 
mening dat wanneer kommunisme die kapitalisme sou oorwin, die gepaardgaande klaslose samelewing in 'n bepaalde sin die "einde van die geskiedenis" sou verteenwoordig (Fukuyama se tese kan dus as die teenoorgestelde van Marx s'n beskou word). Hegel se tese oor die einde van die kuns as draer van die ontvouende gees het dus niks hiermee te doen nie.

Ofskoon dit hier as 'n "kunsvorm" bestempel word, moet 'n mens jouself deeglik daarvan vergewis dat ekologiese kuns egter opvallend van ander kunsvorme verskil, wat besonder duidelik blyk wanneer Goldsworthy se "kunswerke" onder die loep geneem word. In sy artistieke praktyk gaan Goldsworthy byvoorbeeld nie met die natuur as "voorwerp" of "objek" om, soos wat in tradisionele kunspraktyk die geval is nie, maar "laat die natuur met rus" ooreenkomstig Martin Heidegger se beginsel van Gelassenheit ("letting be"; Heidegger 1966:53-54, 61). Dit wil sê, dat Goldsworthy se ekokunswerke natuurlike prosesse soos verwarming, afkoeling (vries), groei en vergaan of verrotting hul natuurlike gang laat gaan, selfs al is dit so dat die konstruksie van sy kunswerke op vlietende wyse by die natuur ingryp by wyse van 'n "herrangskikking" van natuurlike voorwerpe, sonder om laasgenoemde egter in die proses te verobjektiveer. Daarenteen bly sy "rangskikkings" onderworpe aan die natuurprosesse waarna hier bo verwys is, en kan hulle dus tereg as "kortstondige kunswerke" beskou word. Samehangend hiermee is dit betekenisvol dat een van sy boeke (deur homself geskryf) die veelseggende titel dra van Andy Goldsworthy - A Collaboration with Nature (1990), wat eweneens impliseer dat daar by hom geen sprake is daarvan om die natuur, of trouens enige natuurgegewe, as “objek" te konstitueer nie. Dit is ook 'n eksplisiete aanduiding van die semantiese afstand tussen sy kuns en tradisionele kuns, vir sover laasgenoemde deur onafhanklike, outonome individue geskep is deur natuurlike materiale te benut om relatiefduursame objekte, bekend as "kunswerke" daarmee saam te stel, vanaf skilderye en beeldhouwerke tot argitektoniese werke. Vergeleke hiermee is Goldsworthy se ingryping in die natuur minimaal (Beyst 2002:1-3), en bou hy sy "beeldhouwerke" of strukture met dorings, blomme, blare, takkies, modder, sneeu, yskeëls, klippe of opeengestapelde rotse, waar laasgenoemde waarskynlik die "duursaamste" (maar steeds verganklike) van sy kunswerke is (sien "Andy Goldsworthy artworks" vir relevante illustrasies van sy kuns). Die enigste relatief duursame items wat met hierdie strukture verband hou, is die foto's (en fotografiese reproduksies) daarvan, geneem ten tye van wat Goldsworthy (1990) as die hoogtepunt van die natuursiklus waarvan dit deel uitmaak, beskou - met die belangrike kwalifikasie dat hierdie foto's bloot 'n argief of rekord van die kunswerke daarstel, en nie self aanspraak maak op artistieke status nie. Hierdie radikaliteit van Goldsworthy se artistieke praktyk, veral in vergelyking met tradisionele kunspraktyke, blyk duidelik uit sy eie weergawe van sy modus operandi (Goldsworthy 1990:2, 4):

Movement, change, light, growth and decay are the lifeblood of nature, the energies that I try to tap through my work. I need the shock of touch, the resistance of place, materials and weather, the earth as my source. I want to get under the surface. When I work with a leaf, rock, stick, it is not just that material in itself, it is an opening into the processes of life within and around it. When I leave it, these processes continue...At its most successful, my 'touch' looks into the heart of nature; most days I don't even get close. These things are all part of a transient process that I cannot understand unless my touch is also transient - only in this way can the cycle remain unbroken and the process be complete.

Wat kan 'n mens hierin lees? Dat Goldsworthy “kuns” ooreenkomstig die siklus van geboorte, groei, vergaan, dood en herlewing beoefen, welke siklus met die kultus van die god Dionysos 
in Antieke Griekeland geassosieer word (Shlain 1998:136-148). Hiervolgens is die periodieke seisoenale "herlewing" van die natuur met die aanbreek van Lente gevier, wat op die oënskynlike "dood" gedurende Winter gevolg het. Met ander woorde, uit sy selfrefleksiewe beskrywing blyk dat Goldsworthy homself as iemand sien wat kuns ooreenkomstig die natuur se "wette" beoefen, waarvolgens hy natuurlike ritmes en siklusse respekteer, ofskoon dit gepaardgaan met 'n bepaalde kreatiewe, tasbare "ingryping" in natuurprosesse, sonder om die natuur se integriteit te skaad. Desnietemin kan 'n mens nie, met die (gedeeltelike) neutralisering van die tradisionele menslike kunstenaar-as-agent, tot die slotsom kom dat die natuur self die rol van kunstenaar oorneem nie; wat by Goldsworthy aangetref word, is 'n "samewerking" tussen menslike kunstenaar en die natuur - 'n wederkerigheid of vennootskap van wedersydse bydrae tot die kunsskepping. Ten einde sy kenmerkende "kunswerke" die lig te laat sien, moet Goldsworthy homself "instem" op die vereistes wat die eienskappe van bepaalde materiale (soos klip, ys, hout, blare, ensovoorts), asook die genius loci van die plek waar hulle teëgekom word, aan hom stel. Sy ingesteldheid teenoor hierdie natuurlike stowwe kan as 'n "hermeneutiek van luister" beskou word, wat hom in staat stel om 'n wedersyds kreatiewe, prosesgeoriënteerde verhouding met hulle te bewerkstellig. Die musikale metafoor van "ingestem wees op" ("attunement to") is besonder geskik om die aard van hierdie paradigmaties-ekologiese kunspraktyk saam te vat.

Indien 'n mens nie vertroud is met enige vorm van ekologiese kuns nie, mag jy wonder waar die wortels van Goldsworthy se uitsonderlike kuns lê, en tweedens, in watter sin dit as "kritiese" kuns (soos wat Hegel geantisipeer het) verstaan kan word. Wat die eerste vraag betref, is 'n goeie beginpunt Vaclav Havel (1996:213) se verwysing na die sogenaamde Gaiateorie (sien ook Lovelock 2010) - die opvatting dat die aarde 'n reusagtige makro-organisme is, en nie bloot 'n neutrale planetêre ruimte wat 'n verskeidenheid van organismes "bevat" nie:

This theory brings together proof that the dense network of mutual interactions between the organic and inorganic portions of the Earth's surface form a single system, a kind of mega-organism, a living planet - Gaia - named after an ancient goddess who is recognizable as an archetype of the Earth Mother in perhaps all religions. According to the Gaia Hypothesis we are parts of a greater whole. Our destiny is not dependent merely on what we do for ourselves but also on what we do for Gaia as a whole. If we endanger her, she will dispense with us in the interests of a higher value - that is, life itself.

Hieruit kan 'n mens aflei dat die weg teoreties voorberei is vir ekologiese kuns met die groeiende besef dat die menslike spesie nie, soos wat antroposentriese denkers (onder andere René Descartes) in die moderne era gemeen het, die middelpunt van alle synsvorme uitmaak nie, maar eerder een van vele spesies is wat in 'n verhouding van wederkerigheid met die planetêre ekosfeer verkeer. Hierdie besef is ook in Marilyn French (1986:542-544) se werk waarneembaar, waar sy die kontemporêre (letterlik postmoderne) natuurbeeld as 'n haas onbegrypbaar komplekse, oop, onderling verbonde totaliteit van wedersydse verhoudinge karakteriseer. Sodanige strukturele kompleksiteit en wederkerigheid het nie slegs op natuurlike (asook sosiale) ekosisteme betrekking nie - wat impliseer dat, in die geval van ekologiese kunspraktyk, die waarnemer daarby ingesluit is; dit is ook op subatomiese "waarskynlikhede van interkonneksie" van toepassing. Dit is treffend dat sowel Havel as French die onderlinge verbondenheid van alle entiteite beklemtoon, waarmee hulle die foutiewe denke van vroeër, naamlik om dinge in isolasie van mekaar te beskou, effektief as sodanig ontmasker. Te oordeel aan 
Goldsworthy se voorbeeld is ekologiese kuns egter juis op die deelnemende ("participatory") verhouding tussen kunstenaar en natuur (of samelewing, in die geval van ekososiale kunstenaars soos Bradley McCallum; sien Gablik 1993:303-305) afgestem, wat geensins verbasend is nie. Immers: 'n (natuurlike of sosiale) ekologie kom volgens Kovel (2002:17) neer op "'n geheel wat deur interne verhoudinge gedefinieer word" ("a whole defined by internal relations"). Dit impliseer dat kunstenaar (mens) en ekologiese geheel nie van mekaar geskei kan word nie; hulle vorm 'n geheel.

Suzi Gablik brei in haar werk oor ekologiese kuns uit op die tema van interkonnektiwiteit en individuele deelname aan omvattende totaliteite, en situeer dit in verhouding tot die omverwerping van die "moderne self". Gablik se essay, "Toward an ecological self" (1993:301309 ), verteenwoordig 'n vroeë aanduiding van rigtingwysers in ekologiese denke, en meer spesifiek met betrekking tot kuns. Die frase, "ekologiese self", is belangrik hier. Volgens Gablik, soos inderdaad ook die geval is vir die denkers waarna sy verwys, is die tydgenootlike verskyning van die "relasionele self" - dié self wat in en deur die talryke verhoudinge waarin dit deurgaans verkeer, gekonstitueer word, en waarskynlik ten beste in die werk van Gilles Deleuze en Félix Guattari (1987; sien ook Olivier 2017) na vore kom - simptomaties van die ondergang van moderniteit en samehangend daarmee die sogenaamde Cartesiaanse selfbeeld. Kenmerkend van laasgenoemde is veronderstelde self-deursigtigheid en outonomie, gepaardgaande met ontologiese isolasie, wat opvallend kontrasteer met die tans voorkomende relasionele selfbeeld, wat die "ingevoegdheid" van die self in 'n web van sosiale en natuurlike verhoudinge met "ander" selwe, asook andersoortige wesens, beklemtoon (Braidotti 2013).

Die paradigmaties-moderne "sisteem van oorheersing" ("dominator-system"; Gablik 1993), wat in die antroposentriese moderne wêreldbeeld gefundeer is, en waarvan die ontwikkeling van moderne wetenskap en tegnologie (Heidegger 1977), sowel as die natuurverwoestende kapitalistiese ekonomiese sisteem wat vroeër bespreek is, as manifestasies beskou kan word, het nie slegs op hierdie drie samelewingsverskynsels betrekking nie. Selfs die moderne kuns (as beliggaming van Hegel se "kritiese" en teoreties georiënteerde "postkuns") kan nie kwytgeskeld word van die aanklag dat dit, soortgelyk aan die wetenskap, tegnologie en ekonomie, die werklikheid objektiveer nie. Dit is geen toeval dat Schopenhauer (1969:185) reeds in die 19de eeu daarvan kon sê dat: “....art...plucks the object of its contemplation from the stream of the world's course, and holds it isolated before it....it stops the wheel of time; for it the relations vanish; its object is only the essential..."

Hierdie opmerking van Schopenhauer het te make met die "estetiese" funksie van kuns - spesifiek post-Hegeliaanse moderne kuns - wat verskil van die estetiese waarde wat aan ekologiese kuns toegedig kan word. Wanneer van laasgenoemde, soos byvoorbeeld een van Goldsworthy se ysbeeldhouwerke, beweer word dat hulle estetiese waarde het, kan dit verstaan word om te beteken dat hulle "mooi', dit wil sê, "esteties bevredigend" is. Dit is egter nie wat die "estetiese" waarde van moderne kuns beteken nie, aangesien ekologiese kuns nie gebruik maak van die een of ander konvensionele (moderne) "raam" as estetiserende middel nie ekologiese kuns is "raamloos" met die natuurlike omgewing geïntegreer, wat juis die kritiese (post-Hegeliaanse) potensiaal daarvan moontlik maak. Die modernistiese "raam" het die funksie om die kunswerk as estetiese ruimte af te sonder van die alledaagse, pragmatiese leefwêreld, insluitende die natuur, en dit sodoende in staat stel om op eie-aardige wyse die samelewing aan die hand van artistieke middele soos metaforiese beelde te kritiseer. 'n Bekende voorbeeld hiervan is Pablo Picasso se Guernica, waar stilisties verwronge beelde van onder andere 'n vrou, 'n perd en 'n bul die afgryse van die Fascistiese lugaanval op die Spaanse dorpie met dié naam (Guernica) in 1937 onmiskenbaar metafories uitbeeld. 
Om die implikasies hiervan duideliker te stel, kan 'n modernistiese skildery soos Newburyport van Frank Stella (Harries 1997:16-17; sien ook Harries 1968) in oënskou geneem word (vir die begripmatige verskille tussen die begrippe modern, modernisties, postmodern en postmodernisties, sien Olivier 2013). In sy bespreking van Newburyport wys Harries daarop dat dit, as "estetiese objek", sigself as 'n "selfgenoegsame geheel" ("self-sufficient whole") aanbied, dat dit "estetiese afstand vereis" ("demands aesthetic distance"), en dat dit die toeskouer tot 'n "oorvloed van estetiese ervaring" ("plenitude of aesthetic experience") toegang gee, omdat dit oor geen pragmatiese nut beskik nie; inteendeel - as estetiese objek hef dit alle menslike betrokkenheid by die alledaagse wêreld se aktiwiteite op. As modernistiese kunswerk is hierdie werk van Stella dus gepredikeer op die beginsel dat die estetiese sfeer, wat as't ware in kuns "gepreserveer" word, die toeskouer bevoorregte epistemologiese en ontologiese toegang bied tot 'n bepaalde soort "waarheid" en "werklikheid" (wat alleenlik via kunswerke op daardie wyse toegeëien kan word). Daarby moet onthou word dat die kunsmuseums en galerye waar sodanige tradisionele moderne kunswerke gewoonlik hang of uitgestal word, bydra tot die "estetiese afstand", of selfs vervreemding tussen (moderne) kuns en die wêreld vanweë die feit dat sodanige ruimtes in 'n bepaalde sin "konteksloos" is, met ander woorde dat hulle op 'n de-kontekstualiserende wyse funksioneer. Nodeloos om te beklemtoon, is hierdie kenmerk van museumruimtes oor die algemeen - behalwe waar daar doelbewus gepoog word om dit teë te werk - volkome in harmonie met die "estetisisme" van moderne kunswerke, en spesifiek met modernistiese werke, wat hulself van ander moderne kuns onderskei vir sover die estetiese as ontologies gedifferensieerde ruimte refleksief in en deur modernistiese werke getematiseer word. 'n Voorbeeld hiervan is Robert Rauschenberg se abstrakte skildery, Satellite (in die Whitney Museum van Amerikaanse Kuns in New York), waar die beeld van 'n voël bo-op 'n enkele "raam"-oppervlak, wat die boonste kant van die reghoekige skildery begrens, die estetiese ruimte van die skildery tegelykertyd beklemtoon en problematiseer - die voëlbeeld wat, soos 'n satelliet in verhouding tot die aarde, "buite" die skildery gesitueer, en terselfdertyd "deel" van die kunswerk is, is 'n aanduiding van die modernisties-dekonstruktiewe status van hierdie kunswerk.

Uit bostaande behoort dit duidelik te wees dat die "sterk punte" van moderne kuns - dat dit estetiese ruimte as outonoom beskou en hanteer, dat dit 'n wig tussen die kunswerk en die wêreld indryf, ensovoorts - terselfdertyd ook die "swak punte" daarvan verteenwoordig. In die geval van sommige verteenwoordigers van modernistiese kuns moet 'n mens egter die belangrike kwalifikasie byvoeg dat - soos Rauschenberg se Satellite illustreer - juis hierdie estetisisme van moderne kuns op refleksiewe wyse geproblematiseer word, en dat dit daarmee 'n stap in die rigting van dié soort kuns neem, wat poog om die gaping tussen sigself en die wêreld te oorbrug. Om die waarheid te sê, deur die driedimensionele beeld van 'n voël bo-op die enkele horisontale oorblyfsel van 'n "raam" te plaas (die res van die skildery is raamloos), antisipeer Rauschenberg juis 'n kunsvorm wat die volgende deurslaggewend kritieke stap neem, om kuns en die wêreld/natuur met mekaar te "vervleg". Ek wil argumenteer dat ekologiese kuns, soos beliggaam in die werk van Andy Goldsworthy, waarskynlik meer as enige ander soort kuns daarin slaag om die kloof wat moderne kuns van die wêreld (insluitende die natuur) geskei het, suksesvol te oorbrug, sonder om egter volkome natuur te word: sy kunswerke bly nog steeds kuns, maar tegelykertyd ook natuur. Hier vind 'n mens kunswerke wat volgens die kenmerkende "sowel...as" logika van poststrukturalisme "werk" (Derrida 2005; Olivier 2007). Bowendien gebeur dit op 'n wyse wat versoenbaar is met Hegel se geantisipeerde "vrye (kritiese) kuns", waar die intellektuele aspek van Goldsworthy se kunswerke, wat hand aan hand met die visuele aspek daarvan funksioneer, nie geïgnoreer kan word nie. 


\section{DIE KRITIESE RADIKALITEIT VAN EKOLOGIESE KUNS}

Dit is egter maklik om die kritiese radikaliteit van ekologiese kuns te onderskat - waar dit in die gees van Hegel se geantisipeerde "kritiese kuns" verstaan moet word. (Dit is egter nie die enigste kunspraktyk wat as krities bestempel kan word nie - ek het vroeër ook na die moderne kuns van die eerste helfte van die 20ste eeu verwys as beliggaming van wat Hegel as postRomantiese, "kritiese kuns" geantisipeer het; Harries 1968; Olivier 1998.) Maar 'n mens kan tereg vra: watter kritiese trefkrag het beeldhouwerke uit klip, of sneeu, of ys, of 'n rots wat bedek is met kleurvolle herfsblare, per slot van sake? My antwoord hierop is dat hulle juis kritiese slaankrag besit omdat hierdie "vlugtige kunswerke" nie soos tradisionele kuns die grens (en afstand) tussen kultuur en natuur "respekteer" nie, maar hierdie twee domeine met mekaar integreer, of miskien meer akkuraat gestel, "vervleg". Waarom is dit dan kwansuis so kragtig as artistieke kritiek? Omrede dit die objektiverende "afstand" tussen kultuur en natuur is wat die grondslag gelê het vir die tegniese "opkommandering" ("ordering") van die natuur deur die tegnologie (Heidegger) - 'n "afstand" wat veral in die natuurwetenskap en die tegnologie beliggaam is, maar selfs in die objektiverende aard van tradisionele (insluitende moderne) kuns na vore kom, soos hier bo aangetoon is. Hier is dit belangrik om kennis te neem van Heidegger se insig dat die wese van tegnologie nie die tegnologie self is nie, maar 'n synswyse verteenwoordig waarvolgens menslike denke, doen en late in die era van tegnologie fundamenteel georden word, en wat hy Gestell ("Enframing"; "be-raming") noem. Soos Heidegger (1977: 20) dit stel:

Enframing means the gathering together of that setting-upon which sets upon man, i.e., challenges him forth, to reveal the real, in the mode of ordering, as standing-reserve. Enframing means that way of revealing which holds sway in the essence of modern technology and which is itself nothing technological.

Kortliks kom dit daarop neer dat Gestell ("Enframing", "be-raming") as synswyse en, korrelatief, as denkwyse fundamenteel bepaal hoe mense die sosiale en natuurlike werklikheid ervaar, naamlik as stof wat opgekommandeer kan word om, as "rou materiaal", op tegniese wyse benut of gebruik te kan word. Langs hierdie weg gaan alle intrinsieke waarde wat iets (soos die natuur) of iemand (soos jou kinders) mag hê, verlore, dit wil sê hul waarde word gereduseer tot blote tegniese bruikbaarheid. In die lig hiervan kan beweer word dat die huidige, steeds verergerende ekologiese krisis gesien en verstaan kan word as die gevolg van die reduksie van die natuur (met die gepaardgaande komplekse onderlinge verbande tussen subsisteme inbegrepe) van 'n omvattende ekologiese geheel tot "rou materiaal" wat in Heideggeriaanse terme "opgekommandeer" word vir die uitsluitlike gebruik van die mens. Dit geld vir water, grond, wind, energie, die bome in reënwoude, diere, en selfs mense - dit is nie toevallig dat wat vroeër as "personeelafdelings" van maatskappye bekendgestaan het, nou "menslike hulpbronne" ("human resources") heet nie. 'n Mens kan ook nie die verband tussen kapitalistiese ekonomie en tegniese eksploitasie van die natuur in hierdie verband oor die hoof sien nie (Pittaway 2017; Olivier 2018). In die lig hiervan is dit dus geensins oordrewe om ekologiese kuns soos dié van Goldsworthy as radikaal krities te bestempel nie: immers, waar kuns tradisioneel miskien wel by geleentheid die skoonheid en wildheid van die natuur verheerlik het, was dit altyd as kultuuruiting, wat met objektivering gepaardgegaan het. Daarenteen maak ekologiese kuns sigself tuis in die natuur - Goldsworthy se "vlietende" kunswerke word in die natuurlandskap gebou, en is daarom terselfdertyd onderworpe aan natuurprosesse van verweer, erosie en verganklikheid. Op hierdie wyse is hulle die konkrete uitdrukking van kultuur- en same- 
lewingskritiek wat op die oorsake van die ekologiese krisis fokus, deurdat hulle implisiet die aandag vestig op die mislukking van menslike kultuur sover dit eerbied vir die natuur as kreatiewe matriks van die lewe aangaan. In 'n neutedop gestel: in plaas daarvan om strategieë te ontwerp waardeur daar saam met die natuur gewerk kan word - wat wel moontlik is, soos wat Michael Braungart en William McDonough sorgvuldig in hul boek, Cradle to Cradle (2009) demonstreer - het mense nog altyd tegnieke gevind om teen die natuur te werk, met ander woorde volgens die patroon van "wieg na graf" ("cradle to grave").

\section{SLOT}

Waartoe hierdie “wieg na graf"-lewenswyse volgens die ontologiese logika van Gestell of "be-raming" gelei het, en waarvan die ekologiese kuns van Goldsworthy ons krities-deelnemend bewusmaak, kan kortliks aangedui word aan die hand van 'n onlangse artikel wat die lewensbelangrike erns van die ekologiese krisis beklemtoon. In 'n resente artikel deur 'n groep internasionale wetenskaplikes (Bradshaw, Ehrlich, Beattie et al. 2021; sien ook Weston 2021), vestig hulle die aandag op die haglike toestand waarin die planetêre biosfeer verkeer. Hier is die opsomming van hul bevindinge:

We report three major and confronting environmental issues that have received little attention and require urgent action. First, we review the evidence that future environmental conditions will be far more dangerous than currently believed. The scale of the threats to the biosphere and all its lifeforms - including humanity - is in fact so great that it is difficult to grasp for even well-informed experts. Second, we ask what political or economic system, or leadership, is prepared to handle the predicted disasters, or even capable of such action. Third, this dire situation places an extraordinary responsibility on scientists to speak out candidly and accurately when engaging with government, business, and the public. We especially draw attention to the lack of appreciation of the enormous challenges to creating a sustainable future. The added stresses to human health, wealth, and wellbeing will perversely diminish our political capacity to mitigate the erosion of ecosystem services on which society depends. The science underlying these issues is strong, but awareness is weak. Without fully appreciating and broadcasting the scale of the problems and the enormity of the solutions required, society will fail to achieve even modest sustainability goals.

Niemand behoort dus, in die lig van hierdie ernstige waarskuwing deur vooraanstaande wetenskaplikes, die afmetinge van die dreigende ekologiese krisis te onderskat nie. Dit is die gevolg van etlike eeue (sedert die moderne Industriële Rewolusie van die laat 18de eeu) se ongebreidelde ekonomiese groei, gepaardgaande met toenemende besoedeling van die atmosfeer en toenemende verlies aan biodiversiteit. Die mens se tegnologiese kundigheid, tesame met kolossale ekonomiese groei, aangewakker deur gierigheid, is onweerlegbaar hiervoor verantwoordelik (Kovel 2002; Foster et al 2010; Klein 2014; Olivier 2018). Die ekologiese kunswerke van Andy Goldsworthy kan as metonimie beskou word van wat die verhouding tussen mens (of kultuur) en natuur behoort te gewees het om die huidige, betreurenswaardige toestand op die planeet te kon voorkom het. Dit mag te laat wees daarvoor, maar dis nie te laat om uit Goldsworthy se radikaal-kritiese, post-Hegeliaanse kuns te leer en te doen wat 'n mens kan om 'n globale katastrofe te verhoed nie. Bowendien sou sodanige handeling, in die aangesig van Goldsworthy se radikaal-kritiese ekokuns, volkome in die gees van Hegel se geprojekteerde "vrye kuns" wees. 
Desnietemin kan by wyse van afsluiting opgemerk word dat ek volmondig saamstem dat, wat 'n konstruktiewe kritikus (een van die anonieme kritiese lesers van hierdie artikel) Goldsworthy se "vervlegte denke" noem (soos deur sy kuns gesuggereer), volgens hom/haar grondig van Hegel (asook Karl Marx) se "dialektiese denke" verskil, en bowendien "tot 'n groot mate bydra tot self-kennis in ons tyd", omdat dit die "meganistiese sisteme" van moderniteit "ontwrig". Hierdie opmerkings sluit aan by wat ek elders (Olivier 2007) aangedui het aan die hand van 'n analogie tussen Goldsworthy se ekokuns, enersyds, en Jacques Derrida se dekonstruktiewe denke, andersyds, waar 'n mens by albei 'n weiering van dialektiek (gekarakteriseer deur die gewaande dialektiese kulminering in 'n finale sintese of versoening tussen teenoorgesteldes) aantref. In die plek daarvan stel albei die werklikheid voor as een van wedersydse verstrengeling van binêre teenoorgesteldes - soos natuur en kultuur - sonder dat die een ooit deur die ander gekanselleer of "opgehef" word. Hulle bestaan eerder voort in 'n toestand van dinamiese spanning, waar die een "teenoorgestelde" voortdurend die ander begrens, soos wat Derrida op uiteenlopende wyses demonstreer, byvoorbeeld in sy dekonstruksie van "(on-)gasvryheid" (sien Olivier 2007), en deur Goldsworthy se ekokunswerke beliggaam word. Elkeen van sodanige kunswerke is tegelyk deel van die natuur en terselfdertyd 'n dinamiese artistiek-kulturele ingryping in natuurprosesse, sonder dat die een die ander "ophef". Nodeloos om by te voeg, sou 'n mens - soos my kritikus opmerk - in die lig van sodanige "poststrukturalistiese" denke en kuns, belangrike selfkennis kon opdoen. Dit is minstens potensieel die geval; te oordeel aan die voortdurende hiërargiese praktyke in die samelewing, soos byvoorbeeld patriargie en outokratiese optrede van regerings gedurende die huidige "pandemie", het sommige mense egter waarskynlik niks daaruit geleer nie.

\section{BIBLIOGRAFIE}

Andy Goldsworthy artworks. Geen datum. https://www.google.com/search? $\mathrm{q}=$ andy+goldsworthy+art works\&tbm $=$ isch\&source $=\mathrm{iu} \& \mathrm{ict} \mathrm{x}=1 \& \mathrm{fir}=\mathrm{u}$ xJU0E-fLrOKM $\% 252 \mathrm{Cczkpsa} 9 \mathrm{v} \quad 6 \mathrm{MLRM} \% 252 \mathrm{C}$ \&vet=1\&usg=AI4 -kQOpANQNZACCvFTeAfAewjJtd1 Vgg\&sa=X\&ved=2ahUKEwjihtGsyZ 3uAhUJAcAKHe6iBfMQ_h16BAgjEAE\#imgrc=u_xJU0E-fLrOKM (Toegang 7 Januarie 2021).

Beyst, S. 2002. Andy Goldsworthy: The beauty of creation. http://d-sites.net/english/goldsworthy.htm, pp. 1-6. (Accessed 4/16/2007).

Bradshaw, CJA, Ehrlich, PR, Beattie, A et al. 2021. Underestimating the challenges of avoiding a ghastly future. Frontiers in Conservation Science: Global Biodiversity Threats, 13 January: https://www. frontiersin.org/articles/10.3389/fcosc.2020.615419/full (Toegang 14 Januarie 2021).

Braungart, M \& McDonough, W. 2009. Cradle to Cradle - Remaking the Way we Make Things. London: Vintage Books.

Deleuze, G \& Guattari, F. 1987. A Thousand Plateaus: Capitalism and Schizophrenia Vol. 2. Vert. Massumi, B. Minneapolis: University of Minnesota Press.

Braidotti, R. 2013. The Posthuman. Cambridge: Polity Press.

Derrida, J. 2005. The principle of hospitality. In: Paper Machine. Trans. Bowlby, R. Stanford: Stanford University Press, pp. 66-69.

Diamond, J. 2005. Collapse. How Societies Choose to Fail or Succeed. New York: Penguin Books.

Foster, JB, Clark, B, \& York, R. 2010. The Ecological Rift. Capitalism's War on the Earth. New York: Monthly Review Press.

French, M. 1986. Beyond Power: On Women, Men and Morals. London: Abacus.

Fukuyama, F. 1992. The End of History and the Last Man. New York: The Free Press.

Gablik, S. 1993. Toward an ecological self. In: Hertz, R. (ed.). Theories of Contemporary Art (Second edition). Englewood Cliffs, NJ: Prentice Hall, pp. 301-309.

Gablik, S. 1998. The Reenchantment of Art. New York: Thames and Hudson.

Goldsworthy, A. 1990. Andy Goldsworthy - A Collaboration with Nature. New York: Harry N Abrams, Inc., Publishers. 
Harries, K. 1968. The Meaning of Modern Art-A Philosophical Interpretation. Evanston: Northwestern University Press.

Harries, K. 1974. Hegel on the future of art. Review of Metaphysics, Vol. XXVII, no. 4, pp. 679-688.

Harries, K. 1997. The Ethical Function of Architecture. Cambridge, Mass.: The MIT Press.

Harries, K. 2009. Hegel's Introduction to Aesthetics. New Haven: Yale University.

Havel, V. 1996. The search for meaning in a global civilization. In: Anderson, WT. The Fontana Postmodernism Reader. London: Fontana Press, pp. 208-214.

Hegel, GWF. 1975. The Philosophy of Fine Art, Vols I and II. Transl. Osmaston, FPB. New York: Hacker Art Books.

Hegel, GWF. 1979. Hegel's Introduction to Aesthetics. Transl. Knox, TM Met 'An interpretative essay', deur C. Karelis. Oxford: Clarendon Press.

Hegel, GWF. 1988. Aesthetics - Lectures on Fine Art. Transl. Knox, TM. Oxford: Clarendon Press.

Hegel, GWF. 2001. The Philosophy of History. Transl. Sibree, J. Kitchener: Batoche Books.

Hegel, GWF. 2018. The Phenomenology of Spirit. Transl. Pinkard, T. Cambridge: Cambridge University Press.

Hegel, GWF. 2010. The Science of Logic. Transl. Di Giovanni, G. Cambridge: Cambridge University Press.

Heidegger, M. 1966. Discourse on Thinking - A Translation of Gelassenheit. Trans. Anderson, JM \& Freund, EH. New York: Harper Torchbooks.

Heidegger, M. 1977. The question concerning technology. In: The Question Concerning Technology and Other Essays. Trans. Lovitt, W. New York: Harper Torchbooks, pp. 3-35.

Klein, N. 2014. This Changes Everything - Capitalism vs the Climate. Toronto: Alfred Knopf.

Kovel, J. 2002. The Enemy of Nature. The End of Capitalism or the End of the World? London \& New York: Zed Books.

Lovelock, J. 2010. The Vanishing Face of Gaia. A Final Warning. London: Penguin Books.

Oelmüller, W. 1969. Die Unbefriedigte Aufklärung. Frankfurt am Main: Suhrkamp Verlag.

Olivier, B. 1998. Contemporary art and Hegel's thesis of the death of art. In: Olivier, B. Critique, Architecture, Culture, Art. Philosophical Essays. Port Elizabeth: University of Port Elizabeth Publications, pp. 7-22.

Olivier, B. 2007. Ecological art and the transformation of society. South African Journal of Art History (SAJAH), 22(1):24-34.

Olivier, B. 2013. Modernism, postmodernism and poststructuralism: The difference. http://www. thoughtleader.co.za/bertolivier/2013/05/24/modernism-postmodernism-and-poststructuralism-thedifference/ (Toegang 24 Mei 2013).

Olivier, B. 2014. The 'Network Society', Social transformation, and the 'Ecological Rift'. Alternation - Interdisciplinary Journal for the Study of the Arts and Humanities in Southern Africa, 21(2):122155.

Olivier, B. 2017. The ethical (and political) status of theorising the subject: Deleuze and Guattari. Psychotherapy and Politics International, 15(2):1-10: http://onlinelibrary.wiley.com/woll/ doi/10.1002/ppi.1408/full.

Olivier, B. 2018. Die ekologiese krisis, kapitalistiese ekonomie en tegno-optimisme. Tydskrif vir geesteswetenskappe, 58(3):464-482.

Pittaway, DA. 2017. Broadening the Context of the Ecological Crisis: Featuring the Orphic and the Promethean. Bloemfontein: Unpublished PhD.thesis.

Princen, T. 2010. Treading Softly. Paths to Ecological Order. Cambridge, Mass.: The MIT Press.

Schopenhauer, A. 1969. The World as Will and Representation, Vol. I. Trans. Payne, EFJ. New York: Dover Publications.

Singer, P. 1983. Hegel - A Very Short Introduction. Oxford: Oxford University Press.

Shlain, L. 1998. The Alphabet vs the Goddess. The Conflict between Word and Image. New York: Penguin Arkana.

Weston, P. 2021. Top scientists warn of "ghastly future of mass extinction" and climate disruption. The Guardian - Environment; 13 January: https:/www.theguardian.com/environment/2021/jan/13/ top-scientists-warn-of-ghastly-future-of-mass-extinction-and-climate-disruption-aoe (Toegang 14 Januarie 2021). 